\title{
RECONSTRUCTION OF THE MONASTERY NEXT TO THE PRAGUE CASTLE
}

\author{
Jakub Řehák ${ }^{a, *}$, Eva Burgetová ${ }^{a}$, Josef ŘEháK ${ }^{b}$, Stanislav Řehák ${ }^{b}$ \\ ${ }^{a}$ Czech Technical University in Prague, Faculty of civil Engineering, Thákurova 7, 166 29 Prague 6, Czech \\ Republic \\ b Speleo-̌̌ehák, Úvoz 6, 11800 Prague 1, Czech Republic \\ * corresponding author: jakub.rehak.1@fsv.cvut.cz
}

\begin{abstract}
The paper deals with a rehabilitation of the historic building of Carmel Monastery next to the Prague Castle. A structural survey of building was carried out and the historical drainage and ventilation system was identified. Based on structural survey in-situ the reasons of failures were analyzed and remedial works of historic monastery were proposed.
\end{abstract}

KEYWORDS: Static failures, rising damp, structural survey, historic drainage systems, natural ventilation, sewer, rehabilitation.

\section{INTRODUCTION}

Protection of buildings from water and moisture relates to the most important measures in ensuring the service life and serviceability of buildings. Of great importance, as well, is structural solution of the designed rehabilitation procedure. Unqualified interventions and measures often lead to failures and in the final phase, the deterioration of the whole complex. For this reason, the problems of long-term efficiency and reliability of rehabilitation methods are becoming a subject of great interest, both in terms of research and practical applications. The focus is mainly on listed buildings where technological designs are the most complicated.

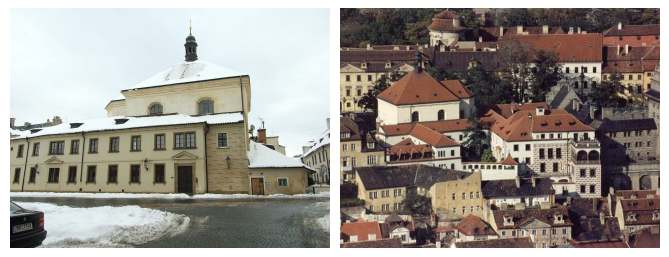

Figure 1. Carmel Monastery in the Prague Castle Square, view to the southern terrace of monastery.

\section{Monastic Water Systems}

Complex water systems in the High Middle Ages was a phenomenon that occurred throughout Europe. Construction of new complex hydraulic systems seems to have begun in the $11^{\text {th }}$ century, and it became increasingly widespread during following centuries. The concentration of water systems looks higher in Germany than elsewhere. The rapid and widespread diffusion of the orders was followed by a rapid and widespread diffusion of hydraulic technology [1]. This technical knowledge of water and drainage systems was brought to Bohemia primarily by Cistercians and
Benedictines as a part of the spread the creed in the $13^{\text {th }}$ century.

The Monastery of Discalced Carmelite nuns (the Carmel of Saint Joseph) is located on the Prague Castle Square. A part of the monastery grounds is the St Benedict's Church, first mentioned in 1353, later the church underwent a number of reconstructions. In 1626 the monastery complex was added to it. Its present form dates back to the middle of the $18^{\text {th }}$ century. The Carmel Monastery was built on a steep south side of the castle promontory (Fig. 11 and 4). The subsoil consists of weathered clay schist, which are unstable and slushy. In the Middle Ages a number of drainage and ventilation systems had served to prevent penetration of moisture into the structures, they drained water and dampness out of the structures and maintained them reasonably dry [2]. The Baroque monastery buildings were forcibly abandoned in 1950 and the entire complex was costly adapted for use as a luxury hotel. Between 1985 and 1991, the monastery underwent extensive reconstruction and was returned to its original religious purpose in 1992.

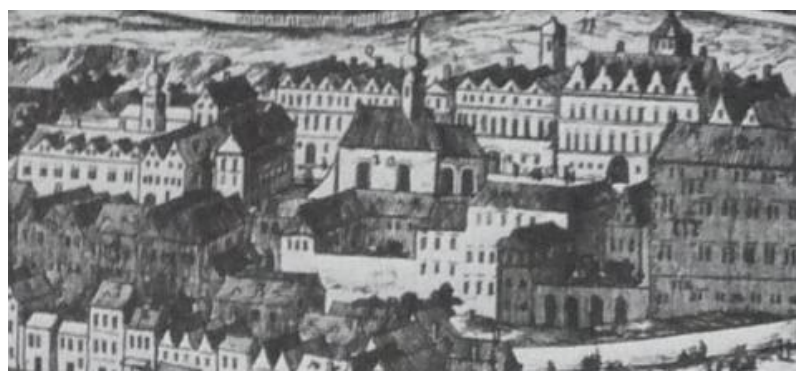

Figure 2. Carmel Monastery - View of Prague by F. van Ouden Allen, 1685.

However, serious static problems manifesting by cracks have appeared and the building was moving slightly downhill to the street Radniční schody (Townhall Stairs). According to the report based on visual 
inspection it was proposed to stabilize the building by grouting of the foundations and by fixing with reinforced ring beam and ties (Fig. 3). The costs of remedial measures were estimated at almost CZK 100 million, which was above the possibility of the nuns, as the owner of the building.

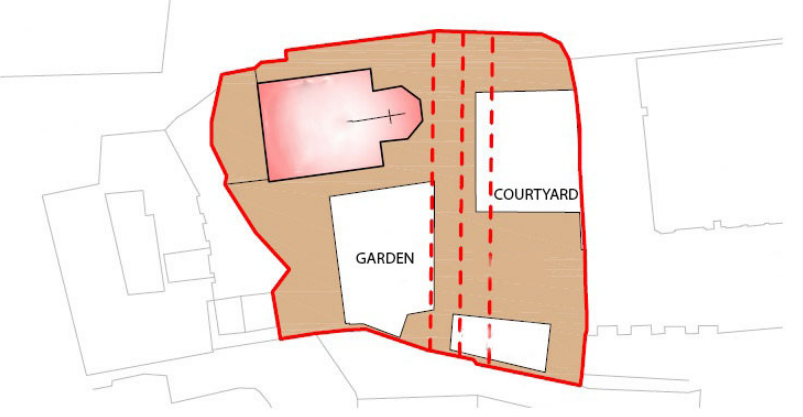

Figure 3. Carmel Monastery: Proposed remedial measures.

\section{EXPERIMENTAL METHODS}

Therefore Carmelite nuns have addressed SPELEOŘehák company, specialized in rehabilitation of drainage systems and associated failures in historic buildings. During the subsequent structural surveys serious problems, that were causing the stability disruption, were revealed.

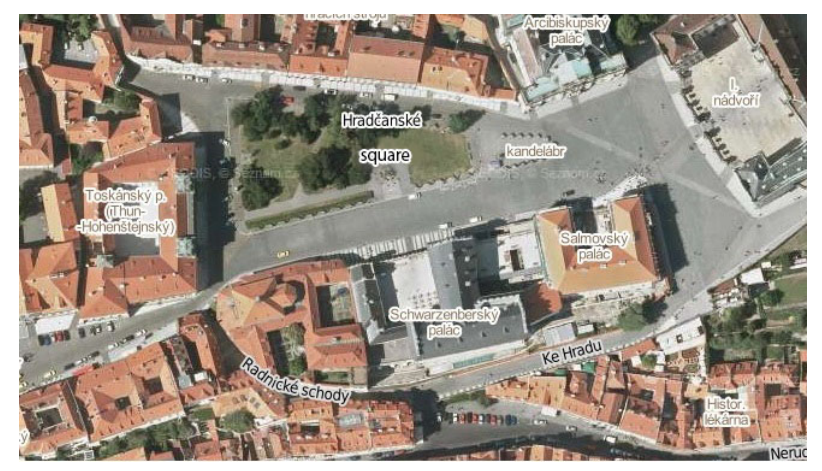

FiguRE 4. Location of the monastery on a steep south side of the castle promontory between Prague Castle Square and Radniční schody (Town Hall Stairs).

Historic drainage systems, however by ignorance of their importance and function, were clogged or filled up during reconstruction, possibly walled up as unnecessarily due to amateurish or inadequately carried out surveys or due to ignorance or negligence of geological and hydrogeological conditions. Lessons from the functioning of these systems and their importance are unfortunately often acquired negatively during the laborious repairing of damage caused by undue interference in their functions.

Stability disruption of masonry of the Carmel Monastery causing its degradation was the result of interaction between multiple negative effects listed below:
- Leaking pipes

The first defect was diagnosed in the main courtyard of the monastery. After realization of the borehole into the damaged masonry and the following extraction of the wet fill, the cause of the problem was discovered - a leaking waste pipe. The water from the pipeline flowed through the backfill and saturated the adjacent structures with water.

- Closure of the main gallery

At the same time, by the drill hole the rest of a lateral gallery was discovered. The main gallery, according to later found historical documentation, led originally from fountain in the courtyard, but later was closed and abolished. The whole area, as it turned out, belonged to the historic drainage system of the monastery and was covered with earth and debris. From this part of underground, about 70 tons of building waste - probably from the time of reconstruction in the 1990s before the return of the monastery to the nuns, was removed.

- Collapse of the gallery walls

The side walls of gallery have collapsed due to lack of maintenance of the underground system. This resulted in the vault falling in and the cavern originated here. If this situation is not solved, it could threaten imminently the surrounding buildings.

- Break of the toilet pit

In the main gallery, fully filled up with rubbish, under monastery corridor the toilet (latrine) pit was discovered. The pit originally led up to the first floor, where it gradually moved into the size of a larger chimney and was led up to the roof. Thanks to the chimney effect, this shaft provided sufficient air dynamics to help drying of the entire building through the drainage system. The chimney effect produced a negative pressure in the system, ensuring the odor from the pit will remove above the roof and at the same time preventing the odor from entering the building. During the reconstruction of the monastery, after the expulsion of the nuns in the 1950 s, this toilet pit was interrupted on the ground floor by the corridor, thus preventing natural air flow and effective drying of the building.

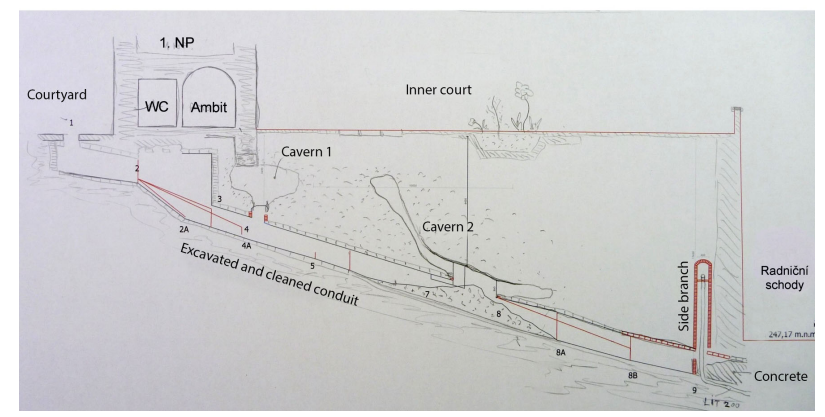

Figure 5. Carmel Monastery: cross section of the main gallery with marks of the caverns.

- Exposed footing bottom 
Behind the toilet pit below the perimeter wall a large cavern with a diameter of 2.5 - 3 meters was discovered. Looking from the gallery to the cavern, the footing bottom of perimeter wall in length of about $2 \mathrm{~m}$ is suspended "in the air" (without contact with subsoil). Exposed footing bottom could not fulfill its function of transferring the load to the subsoil. The reason for the cavern was the total neglect and subsequent destruction of the underground system in combination with insufficient rainfall down pipe during the aforementioned rebuilding. Water leaking from rainfall pipe saturated soil resulted in form of a cavern under the footing bottom.

- The gallery clogged with concrete

In 2013, due to removing of waste fill and rubbish, new part of historic underground drainage system was found. Newly discovered gallery led up to the edge of the retaining wall of the monastery terrace. However, the gallery was filled up with concrete at the level of the retaining wall foundation. It is clear, that the drainage system continues further down below the Radniční Stairs and ensures the drainage of moisture and water also for the houses laid down below, where the survey subsequently confirmed this assumption. By blocking the gallery, the system could not perform its function. In addition, before the concrete "plug", leaking sewage pipe is connected to the gallery, which explains the critical state of the plaster on the supporting wall of Radniční Stairs. Spalling of the plaster was caused by a leaking pipeline that supplied backfill by water, so it functioned as a water reservoir and constantly subsidize the support wall with moisture.

The survey carried out in the Carmel Monastery showed, that moisture imminently threatened construction and represented a heavy burden for the entire building.

\section{The PROPOSAL FOR REDEVELOPMENT}

There are in principle two possible approaches for proposal of moisture redevelopment:

- to fully respect and rehabilitate the original historical moisture proofing methods based on the ventilation of moist air from the structures, while assessing their options in relation to the existing use of the building. The results of applying these methods will take effect in the long term and require careful maintenance 3 .

- to use of the latest technologies and materials, which are a perfect for sealing surfaces (e.g. grouting, waterproofing sealants etc.). This method is fast, the results will come immediately after application, but this is an irreversible action on the historic building [3].

Restoration of traditional systems of protection of buildings from water and moisture should be pri-

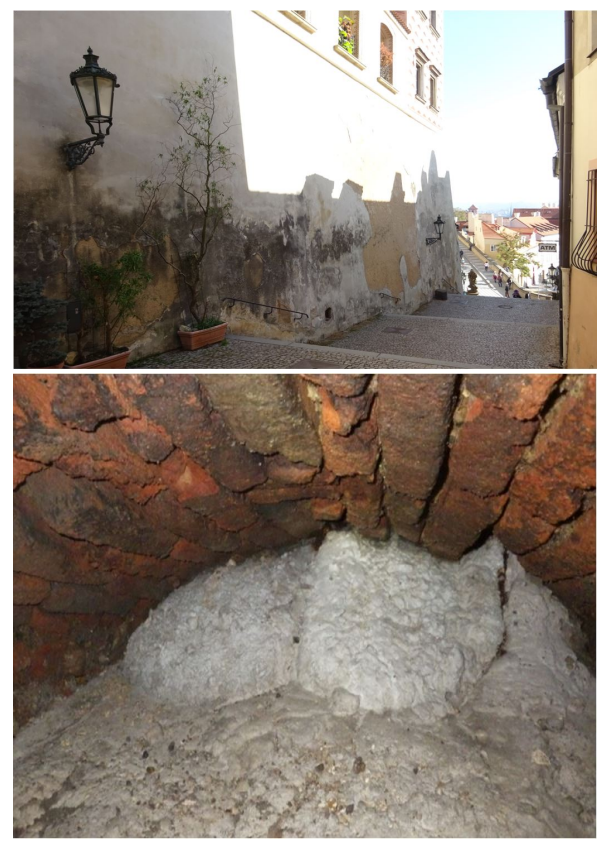

Figure 6. Carmel Monastery: Radniční Schody (Town Hall Stairs) - spalling of the plaster due to water-saturated backfill, the gallery clogged with concrete.

oritized over unsuitable contemporary methods or costly technological measures. Based on the results of the survey and analysis of the failures of the Carmel Monastery the rehabilitation procedures that pose minimal intervention into the structure, were designed in the context of the entire historic area. With an emphasis on the heritage value of the building it was used the original historical technologies for removal of moisture based on the principle of natural venting dampness from the structures.

Water-saturated backfill was manually removed, sewer pipes were repaired, opened up and unwanted ground water discharged from the building. The connection to a ventilation shaft was completed. Moisture from the gallery is now diverted into the cleaned ventilation shaft and due to the chimney effect permeates up through the building above the roof. At present, the galleries of the old system have been mended and they serve as drains and part of the measures securing the building from moisture.

\section{Evaluation of Remediation}

Currently, it can be stated that the drainage and ventilation system is functional and moisture regime in building is stabilized. Realized remedial variant has proved to be functional and effective - within three years it has completely succeeded in drying the walls. The process of plastic deformation with cracking was stopped, cracks were bonded and sliding stabilized. It is clear, that these measures are sufficiently effective to prevent any further development of former structural problems, no other structural intervention were needed. 


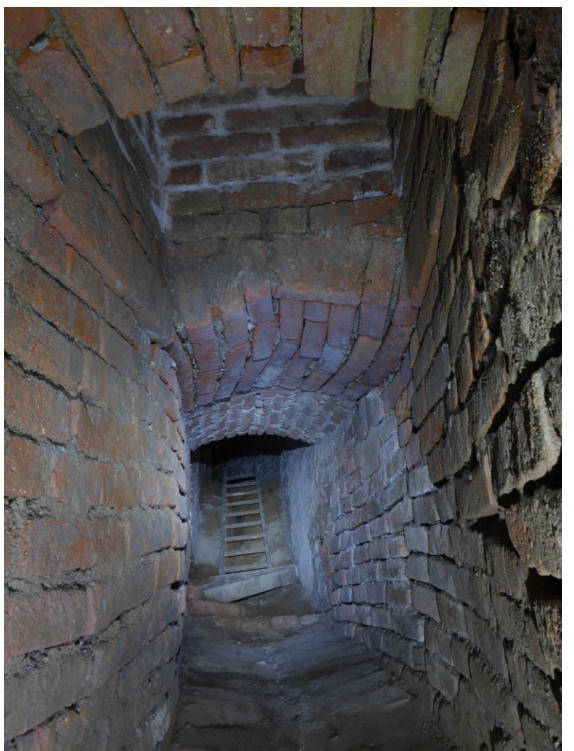

Figure 7. Carmel Monastery: reconstructed main gallery.

Investigation involving the testing of rehabilitation methods and procedures in existing buildings is apparently the most reliable approach for obtaining conclusive results on the effectiveness of damp-removal measures. The experimental testing is useful not only for the assessment of the efficiency of remedial technologies, but also for a deeper investigation of moisture transport phenomena 4]. This appears an attractive way for better approaching the real features of building materials and, at the same time actual climatic conditions experienced on site. The phenomenon of moisture movement is extremely variable from case to case, depending on the specific features of the masonry: direction, quantity and continuity of water supply from ground, depending on seasonal and accidental factors, evaporation condition, thickness and arrangement of the bricks in the masonry, nature of mortar joints etc. 4.

In 2019 the long term monitoring supported by the European structural and investment funds, OP Prague: Analysis of feasibility, Concept DK-07, "Measurement system for tests and verification of the algorithm for description of properties and functions of the historic conduits" will verify the remedial measures carried out in the Carmel monastery. Testing of the moisture transport in historic drainage and ventilation system in the Carmel Monastery will use climatic and microclimatic data which allowed estimating quite accurately the indoor and outdoor evaporation. The efficiency of the air system will be monitored through the velocity and direction of airflow in the system. The collected data could allow the visual presentation of the behaviour of treated structures, its prediction and could help in the design of remedial measures as well.

\section{Conclusions}

The survey of the monastery gave an overview of the hydrogeological situation of this locality and identified the historic drainage and ventilation system. The solution of historic waterproofing was found and respected and - based on its effectiveness - was rehabilitated. Crucial places, where water accumulated, were eliminated by opening up the gallery and cleaning the shaft. The sewer pipes were repaired completely. Thus at the same time air circulation was restored and the high air humidity removed from the building. Underground drainage systems are important and inseparable part of the historic monument, to complement its building history and have for its existence and preservation of its irreplaceable function.

In historical buildings, it is desirable within the investigation of moisture conditions to identify, properly understand and restore the frequently faulty or damaged original insulation, ventilation or drainage systems, which was based on many years of experience of traditional building [5]. The understanding of the original or older solution, its technical parameters and performance is the first step towards finding out the causes of potential failures of the building and their removal allowing, at the same time, restoration of the function of the waterproofing system [6].

The reconstruction of historical drainage systems belongs to the basic tasks of conservation of buildings. Experience of numerous cloister complexes show that the principal cause of increased ground moisture content and changes in subsoil manifested through structural failures of buildings is the breakdown of older drainage and ventilation systems [5]. The case of the Carmel Monastery confirmed that certain static failures and defects can be solved by additional treatment of moisture regime in building subsoil only and the application of invasive static remedial interventions is not necessary. At present, the galleries of the historic system have been mended and served as drains and sliding accompanied by cracking was prevented. The long term measurements of moisture movement verifying the remedial measures are planned in 2019.

\section{REFERENCES}

[1] R. Magnusson. Water Technology in the Middle Ages: Cities, Monasteries, and Waterworks after the Roman Empire. Baltimore: Johns Hopkins University Press, 2001.

[2] J. Řehák. Speleological Survey of Schwarzenberg Palace - Praha 1, Hradčanské nám. čp. 185. 2000. Speleo-Josef Řehák, archiv Speleo.

[3] E. Burgetová, K. Michalová. A Survey of Historic Galleries in the Area of the Prague Castle. In Advanced Materials Research, vol. 1122, pp. 61-64. Trans Tech Publ, 2015.

[4] E. Franzoni. Rising damp removal from historical masonries: a still open challenge. Construction and Building Materials 54:123-136, 2014. 
[5] E. Burgetová. Analysis of rehabilitation methods for rising damp in masonry 2005. Habilitation thesis.

[6] J. Řehák, E. Burgetová, J. Řehák. Moisture Survey of Former Convent in the Vicinity of Prague Castle 2017.

Engineering Material. 